Arch. Tierz., Dummerstorf 47 (2004) 3, 225-230

Institute of Genetics and Animal Breeding, Jastrzębiec, Wólka Kosowska, Poland

ADAM KOŁĄTAJ, EDWARD DYMNICKI, JOLANTA OPRZĄDEK, ARTUR JÓŹWIK, ANNA ŚLIWA-JÓŹWIK and ARTUR OPRZĄDEK

\title{
Influence of starvation and sex on some lysosomal enzymes activity in young dairy cattle
}

\begin{abstract}
The study included 177 Polish Friesian cattle with an over 75\% Holstein proportion - 117 heifers and 60 young bulls 250 days old. The animals were progeny of 27 AI Holstein sires. All individuals were housed in a tie stall and fed ad libitum silage, hay and concentrate until the $7^{\text {th }}$ month of age. From the $7^{\text {th }}$ to the $8^{\text {th }}$ month of age the animals of both sexes received an ad libitum full concentrate diet. Almost in the all cases the activities of lysosomal enzymes were higher in heifers (except NAG, BGAL, AP). The $48 \mathrm{~h}$ starvation did not influence AAP, LAP, AP, LL, BGLU activity in bulls and BGRD, BGAL, BGLU and NAG in heifers.
\end{abstract}

Key Words: cattle, lysosomal enzymes, blood serum

\section{Zusammenfassung}

Titel der Arbeit: Einfluss des Hungers und Geschlechtes auf die lysosomale Enzymaktivität bei Jungrindern

Die Untersuchungen erfolgten an 117 Färsen und 60 Jungbullen der Rasse Schwarzbunt mit einem HolsteinFriesiananteil von über 75 \% ab einem Alter von 250 Tagen. Die Tiere waren Nachkommen von 27 HolsteinFriesianbullen aus der künstlichen Besamung. Die in Ställen gehaltenen Tiere erhielten bis zum 7. Monat Silage, Heu und Kraftfutter ad libitum. Zwischen dem 7. und 8. Monat erhielten die Tiere beider Geschlechter ad libitum Konzentratfutter. Die Blutentnahme erfolgte bei der Hungergruppe vor und nach einer 48stündigen Nüchterungszeit. Bei den Bullen ergaben sich keine Hungerauswirkungen bei den Enzymen: Alanine Aminopeptydase, Leucine Aminopeptydase, Acid Phosphatase, Lyosomal Esterase und $\beta$-Glucosidase, während dies bei den Färsen für $\beta$-Glucosidase, $\beta$-Glucoronidase und N-Acetyl- $\beta$-Glucosidase zutraf. Bezüglich des Geschlechtereinflusses zeigten die Färsen in fast allen Fällen größere Enzymaktivitäten als die Bullen.

Schlüsselwörter: Jungrinder, lysosomale Enzyme, Blutserum, Hunger, Geschlecht

\section{Introduction}

Numerous opinions confirmed by the results of many research papers point out the importance of the lysosomal complex in the cell, which groups the enzymes degrading the proteins, fats and carbohydrates. In this way the lysosomal complex has been included to a system of adaptation response of animal (HASULIK, 1992; JÓŹWIK et al., 2003 a b; WITEK and KOŁĄTAJ, 2000; WITEK et al., 1999). We already know that lysosomes occur in the protoplasm where, independently of ATP and ubiquitin, the long living proteins are degraded (BERLETT and STADTMAN, 1997). The lysosomal enzymes may also hydrolyze the simple chemical compounds emerging as a result of the catabolism, for further use in the cell (LANKOFF and KOŁACTAJ, 2001). In connection with these data, it seemed interesting to estimate the changes of the activity of some model lysosomal enzymes in the blood plasma of young bulls and heifers maintained in farm conditions, fed normally and starved for a short period. Fasting or restriction of food are a specific types of stress burden, which appears quite 
often in domestic animals (OHSHITA et al., 1986; WITEK and KOŁĄTAJ, 1998). The aim of this study was to determine the influence of starvation and sex on the activity of some lysosomal enzymes in young cattle.

\section{Material and methods}

The study included 177 Polish Friesian cattle with an over 75\% Holstein proportion 117 heifers and 60 young bulls 250 days old. The animals were progeny of 27 AI Holstein sires. All individuals were housed in a tie stall and fed ad libitum silage, hay and concentrate until the $7^{\text {th }}$ month of age. From the $7^{\text {th }}$ to the $8^{\text {th }}$ month of age the animals of both sexes received an ad libitum full concentrate diet. The blood samples were taken from the neck vein before and after 48 hours starvation between $8-10$ a.m. to test tubes containing heparin. During starvation the animals had access to water. The samples were centrifuged for 15 minutes at $20.000 \mathrm{~g}$ in $\mathrm{K}-24$ centrifuge. In the blood serum the following lysosomal enzymes were determined: $\beta$ glucoronidase (BGRD) - EC 3.2.1.31; $\beta$-glucosidase (BGLU) - EC 3.2.1.21; $\mathrm{N}$-acetyl$\beta$-glucosaminidase (NAG) - EC 3.2.1.30; $\beta$-galactosidase (BGAL) - EC 3.2.1.23; lysosomal lipase (LL) - EC 3.1.1.2; alanine aminopepdydase (AAP) - EC 3.4.11.2; leucine aminopeptydase (LAP) - EC 3.4.11.1; acid phosphatase (AP) - EC 3.1.3.2; lysosomal esterase (EL) - EC3.1.1.3.

The activity of BGRD, NAG, BGAL, and AP was determined according to the BARRET's method (1972), LAP - by the method of PFLEIDERER and CELLIERS (1963), AAP by the method of PFLEIDERER et at. (1964), EL and LL by the MAIN'S method (1960). The enzymatic activity was expressed in nMol/mg of protein per hour. Plasma protein was estimated according to the method of KIRSCHKE and WIEDERANDERS (1984).

The reagents used were produced by Sigma (Sigma-Aldrich Corp). The results obtained were analyzed statistically using the following model:

were:

$$
\mathrm{y}_{\mathrm{ijkl}}=\mu+\text { Sire }_{\mathrm{i}}+\text { Sex }_{\mathrm{j}}+\mathrm{T}_{\mathrm{k}}+\mathrm{S}_{\mathrm{l}}+\mathrm{e}_{\mathrm{ijkl}}
$$

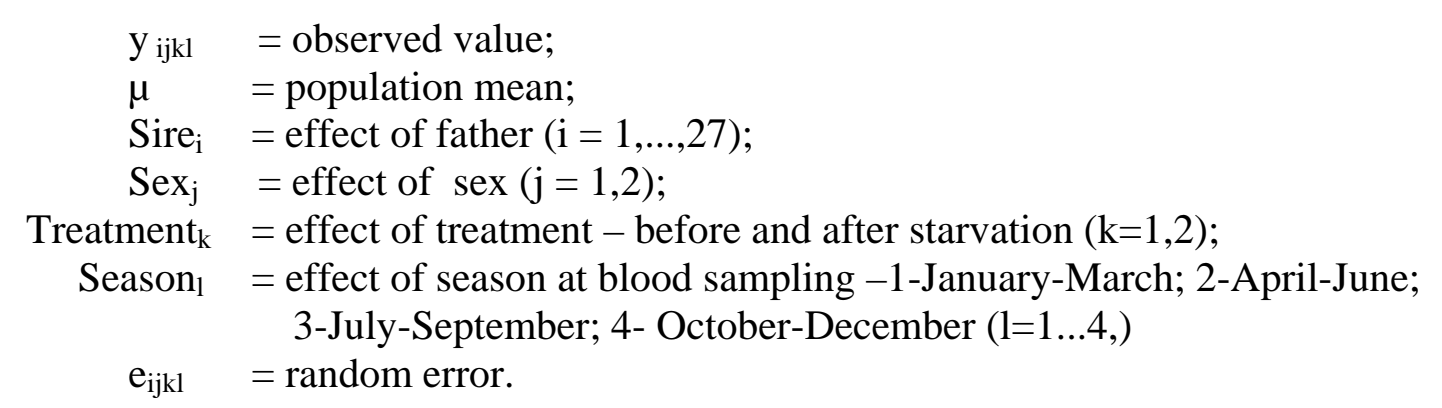

Results

The analysis of variance (Table 1) showed that the enzyme activity is generally influenced by physiological state (starvation), sex, sire, and least by season of blood sampling. Activities of LAP, AP, EL, LL and NAG are influenced by sire. This suggest, that they are genetically determined. AAP, EL, LL, BGLU and NAG are influenced by sex. Season influenced the activity of LAP, AP, and BGAL. The starvation influenced, statistically confirmed, on the activity of all the studied enzymes. The means ( $\overline{\mathrm{x}}$ ) and standard deviation (Sd) are presented in Tables 2 and 3. A great variation for all the analysed enzymes activities can be observed. The 
coefficients of variance for enzyme activity in blood serum sampled before starvation were higher for EL, LL, BGRD and BGLU (bulls) and AAP, BGRD, BGLU (heifers) than after starvation. BGLU and BGRD in both sexes and AAP in heifers showed the highest variation coefficient (55\% and more). A great difference of variances between the sexes was observed for AAP (22.22\% and 79.94\%). The data in Table 4 show that the activity of some studied lysosomal enzymes was influenced by sex (before starvation); for example, activity of NAG , AAP, EL, LL, BGLU and NAG. Almost in the all cases the activities of lysosomal enzymes were higher in heifers (except AP, BGRD, NAG). The starvation did not influence on AAP, LAP, AP, LL, BGLU activity in bulls and BGRD, BGAL, BGLU and NAG in heifers.

Table 1

Effect of different factors on the activity of studies enzymes (Einfluss einzelner Faktoren auf die untersuchten Enzymaktivitäten)

\begin{tabular}{|c|c|c|c|c|c|c|}
\hline No & \multicolumn{2}{|c|}{ Enzyme } & Sire & Sex & Treatment & Season \\
\hline 1. & Alanine aminopeptydase & AAP & N.S & $* *$ & $* *$ & N.S \\
\hline 2. & Leucine aminopeptydase & LAP & $* *$ & N.S & * & $* *$ \\
\hline 3. & Acid phosphatase & AP & * & N.S & ** & ** \\
\hline 4. & Lysosomal esterase & EL & $* *$ & $* *$ & $* *$ & N.S \\
\hline 5. & Lysosomal lipase & LL & * & $* *$ & $* *$ & N.S \\
\hline 6. & $\beta$-glucoronidase & BGRD & N.S & N.S & ** & N.S \\
\hline 7. & $\beta$-galactosidase & BGAL & N.S & N.S & * & $* *$ \\
\hline 8. & $\beta$-glucosidase & BGLU & N.S & ** & * & N.S \\
\hline 9. & N-acetyl- $\beta$-glucosaminida & $\begin{array}{l}\text { se } \\
\text { NAG }\end{array}$ & ** & * & * & N.S \\
\hline
\end{tabular}

Table 2

The activity ( $\overline{\mathrm{X}} \pm \mathrm{Sd}$ ) of estimated enzymes in blood serum of bulls (Enzymaktivitäten im Blutserum der Bullen)

\begin{tabular}{|c|c|c|c|c|c|c|c|c|c|c|}
\hline \multirow{2}{*}{ Enzyme } & \multicolumn{5}{|c|}{ Before starvation } & \multicolumn{5}{|c|}{ After starvation } \\
\hline & $\bar{x}$ & $\pm S d$ & $\mathrm{~V}$ & from & to & $\bar{x}$ & Sd & $\mathrm{V}$ & from & to \\
\hline $\begin{array}{l}\text { Alanine aminopeptidase } \\
\text { AAP }\end{array}$ & 5.31 & 1.18 & 22.22 & 3.22 & 8.43 & 4.47 & 1.40 & 31.32 & 1.91 & 9.05 \\
\hline $\begin{array}{l}\text { Leucine aminopeptidase } \\
\text { LAP }\end{array}$ & 4.79 & 1.14 & 23.95 & 2.97 & 9.21 & 4.54 & 1.31 & 28.85 & 1.89 & 8.91 \\
\hline Acid phosphatase AP & 2.31 & 0.68 & 29.44 & 0.84 & 3.97 & 2.36 & 0.92 & 38.98 & 0.73 & 5.53 \\
\hline Lysosomal esterase EL & 2.25 & 0.88 & 39.11 & 0.02 & 4.10 & 3.82 & 1.01 & 26.44 & 2.19 & 7.35 \\
\hline Lysosomal lipase LL & 0.22 & 0.11 & 50.00 & 0.06 & 0.49 & 0.20 & 0.05 & 25.00 & 0.12 & 0.34 \\
\hline$\beta$-glucoronidase $\mathrm{BGRD}$ & 0.20 & 0.11 & 55.00 & 0.05 & 0.69 & 0.15 & 0.06 & 40.00 & 0.08 & 0.51 \\
\hline$\beta$-galactosidase $\quad$ BGAL & 0.41 & 0.13 & 31.70 & 0.18 & 0.76 & 0.48 & 0.21 & 43.75 & 0.17 & 0.99 \\
\hline$\beta$-glucosidase $\quad$ BGLU & 0.11 & 0.08 & 72.72 & 0.03 & 0.36 & 0.14 & 0.08 & 57.14 & 0.03 & 1.79 \\
\hline $\begin{array}{l}\text { N-acetyl- } \beta \text {-glucosaminidase } \\
\text { NAG }\end{array}$ & 26.74 & 11.43 & 42.74 & 5.88 & 53.45 & 34.98 & 15.08 & 43.11 & 9.01 & 64.43 \\
\hline
\end{tabular}


Table 3

The activity $(\overline{\mathrm{X}}, \pm \mathrm{Sd})$ of estimated enzymes in blood serum of heifers (Enzymaktivitäten im Blutserum der Färsen)

\begin{tabular}{|c|c|c|c|c|c|c|c|c|c|c|}
\hline \multirow{2}{*}{ Enzyme } & \multicolumn{5}{|c|}{ Before starvation } & \multicolumn{5}{|c|}{ After starvation } \\
\hline & $\bar{x}$ & $\pm \mathrm{Sd}$ & $\mathrm{V}$ & from & to & $\bar{x}$ & $\pm \mathrm{Sd}$ & $\mathrm{V}$ & from & to \\
\hline $\begin{array}{l}\text { Alanine aminopeptidase } \\
\text { AAP }\end{array}$ & 7.48 & 5.98 & 79.94 & 3.14 & 9.28 & 5.46 & 1.18 & 21.61 & 2.57 & 9.92 \\
\hline $\begin{array}{l}\text { Leucine aminopeptidase } \\
\text { LAP }\end{array}$ & 5.03 & 0.93 & 18.48 & 2.82 & 7.74 & 4.64 & 0.99 & 21.33 & 2.59 & 7.90 \\
\hline Acid phosphatase AP & 2.18 & 0.63 & 28.89 & 1.05 & 5.52 & 2.68 & 0.91 & 33.95 & 1.10 & 5.44 \\
\hline Lysosomal esterase EL & 4.12 & 0.71 & 17.23 & 2.06 & 5.95 & 3.70 & 0.77 & 20.81 & 2.30 & 5.59 \\
\hline Lysosomal lipase LL & 0.33 & 0.06 & 18.18 & 0.17 & 0.49 & 0.27 & 0.05 & 18.51 & 0.12 & 0.39 \\
\hline$\beta$-glucoronidase BGRD & 0.18 & 0.12 & 66.66 & 0.05 & 1.33 & 0.21 & 0.10 & 47.61 & 0.05 & 0.56 \\
\hline$\beta$-galactosidase $\quad$ BGAL & 0.48 & 0.13 & 27.08 & 0.20 & 0.78 & 0.49 & 0.16 & 32.65 & 0.12 & 0.85 \\
\hline$\beta$-glucosidase $\quad$ BGLU & 0.21 & 0.12 & 57.14 & 0.03 & 0.80 & 0.18 & 0.08 & 44.44 & 0.04 & 0.43 \\
\hline $\begin{array}{l}\text { N-acetyl- } \beta \text { - } \\
\text { glucosaminidase NAG }\end{array}$ & 24.84 & 11.79 & 47.46 & 5.13 & 99.0 & 25.57 & 12.5 & 48.88 & 6.12 & 84.39 \\
\hline
\end{tabular}

Table 4

Analysis of variance for activity of estimated lysosomal enzymes (Varianzanalyse für die lysosomalen Enzymaktivitäten)

\begin{tabular}{|c|c|c|c|c|c|c|}
\hline \multirow{2}{*}{ Enzyme } & \multirow{2}{*}{ sex } & \multicolumn{2}{|c|}{ before starvation } & \multicolumn{2}{|c|}{ after starvation } & \\
\hline & & LSM & Se & LSM & Se & \\
\hline \multirow[t]{2}{*}{ Alanine aminopeptidase AAP } & bulls & $4.74^{\mathrm{A}}$ & 0.53 & $4.51^{\mathrm{A}}$ & 0.51 & N.S \\
\hline & heifers & $6.79^{\mathrm{A}}$ & 0.42 & $4.69^{\mathrm{A}}$ & 0.44 & $* *$ \\
\hline \multirow[t]{2}{*}{ Leucine aminopeptidase LAP } & bulls & 4.56 & 0.14 & 4.82 & 0.14 & N.S \\
\hline & heifers & 5.02 & 0.11 & 4.55 & 0.12 & $* *$ \\
\hline \multirow[t]{2}{*}{ Acid phosphatase AP } & bulls & 2.45 & 0.10 & 2.39 & 0.10 & N.S \\
\hline & heifers & 2.02 & 0.08 & 2.54 & 0.09 & $* *$ \\
\hline \multirow[t]{2}{*}{ Lysosomal esterase EL } & bulls & $3.91^{\mathrm{A}}$ & 0.11 & $2.27^{\mathrm{A}}$ & 0.10 & $* *$ \\
\hline & heifers & $4.07^{\mathrm{A}}$ & 0.08 & $3.70^{\mathrm{A}}$ & 0.09 & $* *$ \\
\hline \multirow[t]{2}{*}{ Lysosomal lipase LL } & bulls & $0.20^{\mathrm{A}}$ & 0.01 & $0.22^{\mathrm{A}}$ & 0.01 & N.S \\
\hline & heifers & $0.34^{\mathrm{A}}$ & 0.01 & $0.27^{\mathrm{A}}$ & 0.01 & $* *$ \\
\hline \multirow[t]{2}{*}{$\beta$-glucoronidase BGRD } & bulls & 0.15 & 0.01 & 0.20 & 0.01 & $*$ \\
\hline & heifers & 0.18 & 0.01 & 0.20 & 0.01 & N.S \\
\hline \multirow[t]{2}{*}{$\beta$-galactosidase $\quad$ BGAL } & bulls & 0.49 & 0.02 & 0.41 & 0.02 & $* *$ \\
\hline & heifers & 0.44 & 0.02 & 0.44 & 0.02 & N.S \\
\hline \multirow[t]{2}{*}{$\beta$-glucosidase $\quad$ BGLU } & bulls & $0.12^{\mathrm{A}}$ & 0.02 & $0.10^{\mathrm{A}}$ & 0.02 & N.S \\
\hline & heifers & $0.23^{\mathrm{A}}$ & 0.01 & $0.22^{\mathrm{A}}$ & 0.02 & N.S \\
\hline \multirow{2}{*}{$\begin{array}{l}\text { N-acetyl- } \beta \text {-glucosaminidase } \\
\text { NAG }\end{array}$} & bulls & $35.4^{\mathrm{a}}$ & 1.78 & 26.2 & 1.65 & $* *$ \\
\hline & heifers & $26.6^{\mathrm{a}}$ & 1.36 & 26.7 & 1.44 & N.S. \\
\hline
\end{tabular}

*- statistically significant $\mathrm{p} \leq 0,05 ; * *$ - statistically significant $\mathrm{p} \leq 0,01$

$\mathrm{a}-$ between sexes $\mathrm{p} \leq 0,05 ; \mathrm{A}-$ between sexes $\mathrm{p} \leq 0,01$

\section{Discussion}

The results indicated a great variation of the studied enzyme activities. Our earlier studies revealed that the activity of the degradation system of the lysosomal compartment is a significant factor maintaining the animal cell in the state of dynamic homeostasis, as well as an important indicator of stress reactivity. Observations conducted on pigs (KOŁĄTAJ et al., 1996), cattle (KOŁĄTAJ et al., 1998), sheep (KOŁĄTAJ et al., 2002) as also on mice (JÓŹWIK et al., 2003 a b; LANKOFF and 
KOŁĄTAJ, 2001; WITEK and KOŁĄTAJ, 1998, 2001), rabbits (KONECKA et al., 2002; WITEK and KOŁĄTAJ, 2000) and quail (WITEK et al., 2000) confirmed this hypothesis. The data obtained from them indicate that the stress factors, employed in these studies, caused the significant changes in the reactivity of the animal cell lysosomal system. Starvation had a distinct effect respectively on some studied lysosomal enzyme activity only. The interpretation of this phenomenon is, as an adaptional system in cattle, difficult to explain.

It is worth emphasise that starvation is a factor changing the homeostasis of animal (CORWIN, 2000; OHSHITA et al., 1986). This stress factor was observed regarding to the lysosomal hydrolases, too (JÓŹWIK et al., 2003 a; WITEK and KOŁĄTAJ, 1998).

The number of studies regarding homeostasis and its disorders in cattle increases, as evoked by different level of nutrition (KIJORA et al., 2002; RICHARDT et al., 2002). Numerous indications of that adaptation has been published but we has failed to find such data regarding the lysosomal degradation enzymes in the blood serum in cattle. It seems that this reactivity may be very interesting in these animals from physiological point of view. There are no bibliographical references about the variability of lysosomal enzyme activities in the cattle.

We think, reactivity of the lysosomal enzymes can be used as indicator of adaptation ability in the cattle too. Because there is a small number of publications on these enzyme activities in cattle the further studies on this area are necessary.

\section{References}

BARRETT, A.J.:

Lysosomal enzymes In “Lysosomes”. A Laboratory Handbook. Dingle J.T. (ed). North-Holland Publ. Co Amsterdam (1972), 46-135

BERLETT, B.S.; STADTMAN, E.R.:

Protein oxidation in agening, disease and oxidative stress. J. Biol. Chem. 272, (1997) 20313-20317

CORWIN, R.L.:

Biological and behavioral consequences of food restriction. Appetite, 34 (2000), 112-113

HASULIK, A.:

The early and late processing of lysosomal enzymes: Proteolysis and compartmentation. Experientia (1992), 130-151

JÓŹWIK, A.; ŚLIWA-JÓŹWIK, A.; BAGNICKA, E.; KOŁĄTAJ, A.:

The influence of selection on reaction to stress in mice. IX. Effect of dietary protein level on activity of lysosomal enzymes in liver and kidney in mice. J. Anim. Breed. Genet. 120 (2003a), 124-131

JÓŹWIK, A.; ŚLIWA-JÓŹWIK, A.; FRONCZYK, W.; KOŁĄTAJ, A.:

Lysosomal enzyme activity in mice in connection with the selection for a high rate of weight gain. Veterinary Medicine 59 (2003b), 348-350

KIRSCHKE, H.; WIEDERANDERS, B.:

Methoden zur Aktivitätsbestimmung von Proteinasen. Martin Luther Universitat, Halle-Wittenberg Wissenschaftl. Beitr. Halle/Salle, (1984), 11-17

KIJORA, C.; PETERS, K.K.; REXROTH, H.; CHOWOLHURY, S.:

Influence of energy level and dietary protein quality and quantity on the lactation performance of German Fawn Goats. Arch. Tierz., Dummerstorf 45 (2002), 255-268

KOŁĄTAJ, A.; BULLA, J.; POLTARSKY, J.; WITEK, B.; KRÓL, T.:

Activities of some leucocyte lysosomal hydrolases of pigs under the effects of diverse stress models. J. Anim. Physiol. Anim. Nutr. 76 (1996), 191-198

KOŁĄTAJ, A., SOMMER, A., WITEK, B., NITRAY, J., FLAK, P.:

The effect of exogenous glucose on the activity of lysosomal enzymes, the glucose and insulin concentration in the blood plasma of young bulls. Arch: Tierz., Dummerstorf 41 (1998), 371-377

KOŁĄTAJ, A.; KLEWIEC, J.; KONECKA, A.M.; JÓŹWIK, A.; ŚLIWA-JÓŻWIK, A.: Influence of protein starvation on some lysosomal enzyme activities in blood serum of sheep. Arch. Tierz., Dummerstorf 45 (2002), 79-85 
KONECKA, A.M.; JEZIERSKI, T.; ŚLIWA-JÓŹWIK, A.; JÓŹWIK, A.; KOŁATAJ, A.:

The effect of cholesterol-enriched diet on the activity of some lysosomal enzymes in the liver blood plasma of rabbits. Arch. Tierz., Dummerstorf 45 (2002), 199-203

LANKOFF, A.; KOŁĄTAJ, A.:

Influence of microcystin-YR and nodularin on the activity of some propteolytic enzymes in mouse liver. Toxicology 146 (2001), 177-185

MAIN, A.R.:

The purification of the enzyme hydrolyzing diethyl p-nitrophenyl phosphate (paraoxon) in sheep serum. J. Biol. Chem. 74 (1960), 11-20

OHSHITA, T.; KOMINAMI, E.; LI, K.; KATUNUMA, K.:

Effect of starvation and refeeding on autophagy and heterophagy in rat liver. J. Biochem. 100 (1986), 623-632

PFLEIDERER, G.; CELLIERS, P. G.; STANULOVIC, M.; WACHSMUTH, D.; BRAUNITZER, G.:

Eigenschaften und analytische Anwendungen Aminopeptidase aus Nierenpartikeln. Biochem. Zeitschr. 340 (1964), 552-564

PFLEIDERER, G.; CELLIERS, P. G.:

Isolierung der Aminopeptidase aus Nierenpartikeln. Biochem. Zeitschr. 339 (1963), 186-189

RICHARDT, W.; JEROCH, H.; SPILKE, J.:

The impact of nutrition and non nutrition factors on milk urea concentration. Arch. Tierz., Dummerstorf 45 (2002), 151-158

TJELLE, T.E.; BRECH, A.; JUVET, L.K.; GRIFFITHS, G.; BERG, T.:

Isolation and characterization of early endosomes and terminal lysosomes:their role in protein degradation. J. Cell. Sci., 109 (1996), 2905-2914

WITEK, B.; KOŁĄTAJ, A.; KRÓL, T.:

Adaptive changes of activity of lysosomal enzymes in the liver, kidneys and spleen of pigs subjected to transport stress. Arch. Tierz., Dummerstorf 39 (1996), 55-59

WITEK, B.; KOŁĄTAJ, A.:

The influence of selection on reaction to stress in mice V. The effect of starvation and gluthatione injection on the activity ofN-acetyl-beta-glucosaminidase and the level of glutathione in the liver. J. Anim. Breed. Genet., 115 (1998), 163-168

WITEK, B.; KOŁAॄTAJ, A.:

The effect of exogenous glucose on the activity of lysosomal enzymes in some organs of rabbits. Arch. Tierz., Dummerstorf 43 (2000), 649-654

WITEK, B.; KOŁĄTAJ, A.; SOBCZYŃSKA, M.:

The influence of selection on reaction to stress in mice. VII. Activity of some lysosomal enzymes in the muscle, spleen, kidney and liver. J. Anim. Breed. Genet., 116 (1999), 311-316

WITEK B., OCHWANOWSKA, E., ŚLIWA, A., KOŁĄTAJ, A.:

Effect of hydrocortisone on the activity of some lysosomal enzymes in mice. Neuroendocrinology Letters, 23 (2002), 83-86

WITEK, B.; KOŁĄTAJ, A.; JEŻEWSKA, G.; WITKOWSKI, A.:

Effect of glucose, glutathione and ethanol on the activity of some lysosomal enzymes in quail. Acta Biologica Cracoviensia Series Zoologia, 42 (2000), 67-72

Received: 2003-07-14

Accepted: 2004-05-14

Corresponding author

Prof. Dr. habil. ADAM KOŁĄTAJ

Institute of Genetics and Animal Breeding PAS

Jastrzębiec, ul. Postępu 1

05-552 Wólka Kosowska

Poland 